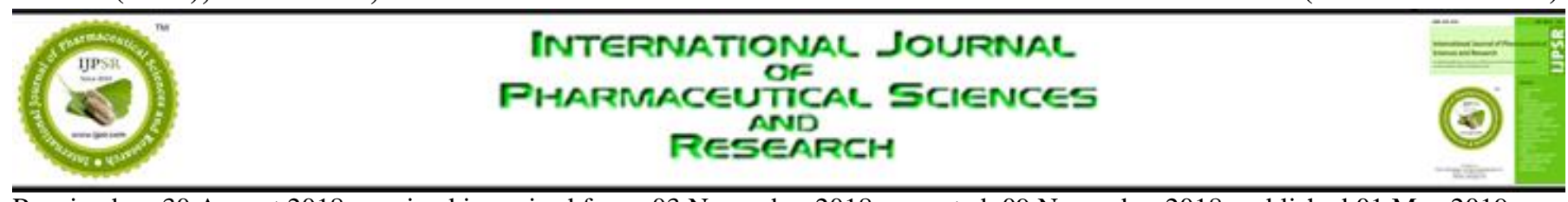

Received on 30 August 2018; received in revised form, 03 November 2018; accepted, 09 November 2018 ; published 01 May 2019

\title{
DEVELOPMENT AND VALIDATION OF STABILITY INDICATING ASSAY METHOD FOR DETERMINATION OF LOXAPINE SUCCINATE IN CAPSULE DOSAGE FORM
}

\author{
Khushbu A. Thakor ${ }^{*}$ and T. Y. Pasha
}

Department of Chemistry, Parul Institute of Pharmacy and Research, Parul University, Limda, Waghodia, Vadodara - 391760, Gujarat, India.

Keywords:

Loxapine succinate, RP-HPLC, ICH, Validation

Correspondence to Author:

Khushbu A. Thakor

Research Scholar, Department of Chemistry, Parul Institute of Pharmacy and Research, Parul University, Limda, Waghodia, Vadodara - 391760, Gujarat, India.

E-mail: thakorkhushbu3@gmail.com
ABSTRACT: To develop and validate simple, selective, specific, sensitive and accurate stability indicating assay method by RP-HPLC for determination of Loxapine succinate in the capsule dosage form. Several trials are taken by changing mobile phase composition, and ratio and finally the drug was eluted on a C18 Purospher star $(250 \mathrm{~mm} \times 4.6 \mathrm{~mm}, 5$ $\mu \mathrm{m})$ column using mobile phase consisting of water: Methanol: Acetonitrile: TEA:: 40:10:50:1 ratio and pumped at flow rate of 1.0 $\mathrm{ml} / \mathrm{min}$ using $10 \mu \mathrm{l}$ injection volume at $254 \mathrm{~nm}$. The Retention time of Loxapine succinate was found to be $10.783 \pm 0.02 \mathrm{~min}$. The calibration curve was linear over concentration range of $75-225 \mu \mathrm{g} / \mathrm{ml}\left(r^{2}=0.999\right)$. The accuracy of the method was estimated by recovery studies and \% recovery was in a range of $98 \%$ to $102 \%$. Stability of Loxapine succinate was studied under different stressed condition like acid, alkali, peroxide, thermal and photolytic conditions. The drug was degraded in all conditions except thermal and photolytic conditions. The developed method was validated as per ICH guidelines.

\section{INTRODUCTION: Loxapine succinate is a} typical antipsychotic drug, member of dibenzoxazepine class and used to treat certain mental or mood disorders (such as schizophrenia). It is a dopamine antagonist and also serotonin 5HT2 blocker. The exact mode of action of Loxapine succinate has not known. This drug helps in reducing aggression and hallucinations (such as hearing/ seeing things that are not occurred). Loxapine is present in capsules as the succinate salt $1,2,3$. Its IUPAC name is 8-chloro-6-(4-methyl piperazine-1yl)benzo[b][1,4] benzoxazepine. Its molecular weight is $445.9 \mathrm{gm} / \mathrm{mole}^{4,5}$.

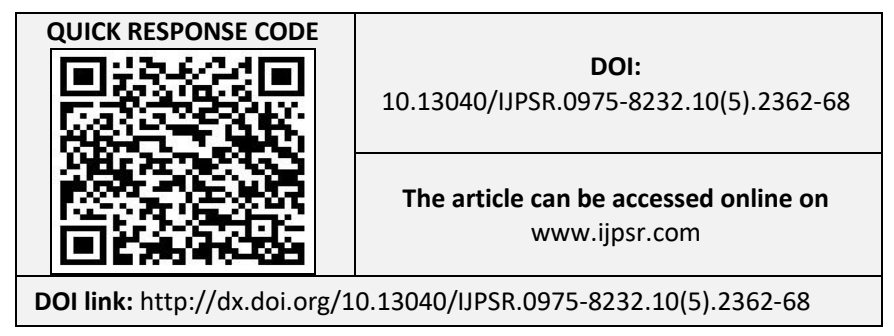

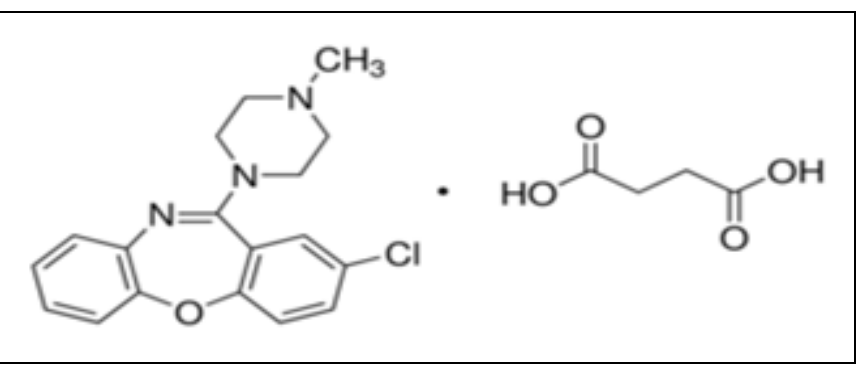

FIG. 1: CHEMICAL STRUCTURE OF LOXAPINE SUCCINATE ${ }^{6,7}$

A literature search reveals that the following methods are reported viz. UV method, HPLC method, HPLC-MS/MS, GC-MS method 8, 9, 10, 11, 12, 13. There is a need for developing stability indicating assay method in the capsule dosage form. So, the authors attempted to develop simple, sensitive, selective and specific stability indicating assay method for determination of Loxapine succinate in a capsule dosage form as per $\mathrm{ICH}$ guidelines ${ }^{14,15,16,17}$. 


\section{MATERIALS AND METHODS:}

Chemicals and Reagents: Loxapine succinate was provided as a gift sample by Hetero Drugs Ltd., Hyderabad, Andhra Pradesh, India. Capsule dosage form was procured from the local market. All the chemicals and reagents like methanol, acetonitrile, water were of HPLC grade and were procured from Merck Specialties Pvt. Ltd., Mumbai, India.

Instrumentation: HPLC waters Alliance 2695 series, equipped with an autosampler, temperature control, and auto-injector with the capacity to inject $5 \mu 1$ to $500 \mu 1$ with PDA detector. Waters HPLC system is equipped with Empower 2 software.

\section{METHODS:}

Experimental Conditions: The HPLC system was operated isocratically at a flow rate of $1.0 \mathrm{ml} / \mathrm{min}$ at $30^{\circ} \mathrm{C}$ column temperature for $30 \mathrm{~min}$. The mobile phase was found to be most suitable for analysis was water: Methanol: Acetonitrile: TEA:: 40:10:50:1 ml which was filtered through $0.45 \mu \mathrm{m}$ PVDF filter. Detection was carried out at $254 \mathrm{~nm}$. The mobile phase is used as a diluent.

Preparation of Standard Solution of Loxapine Succinate: Accurately weighed and Transfer 60 mg of Loxapine succinate into $200 \mathrm{ml}$ volumetric flask. Add diluent about $70 \%$ of flask volume. Sonicate to dissolve and volume made up to mark with diluents. Pipette out $10 \mathrm{ml}$ of the stock solution into $20 \mathrm{ml}$ volumetric flask; volume made up to mark with diluents $(150 \mu \mathrm{g} / \mathrm{ml})$. Results were shown in Fig. 3 and Table 1.

Calibration Curve of Loxapine Succinate: Transfer accurately weighed $30 \mathrm{mg}$ of Loxapine into $50 \mathrm{ml}$ volumetric flask. Add $5 \mathrm{ml}$ of diluent. Sonicate to dissolve, volume made up to mark with diluents $(600 \mu \mathrm{g} / \mathrm{ml})$. from $600 \mu \mathrm{g} / \mathrm{ml}$ appropriate aliquots like $2.5 \mathrm{ml}, 4 \mathrm{ml}, 5 \mathrm{ml}, 6 \mathrm{ml}$, and $7.5 \mathrm{ml}$ taken into $20 \mathrm{ml}$ volumetric flask and made up to mark with diluents, so the resulting solutions become $75,120,150,180$ and $225 \mu \mathrm{g} / \mathrm{ml}$.

Preparation of Sample Solution of Loxapine Succinate: Open 20 capsules and mix and blend powder. Accurately weighed and transferred powder equivalent to $75 \mathrm{mg}$ of loxapine succinate into $50 \mathrm{ml}$ volumetric flask. Add diluent about $50 \%$ of flask volume. Sonicate for $30 \mathrm{~min}$ with intermitting shaking, volume made up to mark with diluent. Solution filter using $0.45 \mu \mathrm{m}$ PVDF filter after $5 \mathrm{ml}$ of filtrate discarded. Pipette out $5 \mathrm{ml}$ of the stock solution into $50 \mathrm{ml}$ volumetric flask; volume made up to mark with diluents $(150 \mu \mathrm{g} / \mathrm{ml})$. Results were shown in Fig. 3 and Table 2.

Method Development and Optimization: During the process of method development, several trials were taken using different aqueous phase, organic phase, different column, good peak shape was observed when using the C18 Purospher star (250 $\mathrm{mm} \times 4.6 \mathrm{~mm}, 5 \mu \mathrm{m})$ column and water: Methanol: Acetonitrile: TEA:: 40:10:50:1 as mobile phase at a flow rate of $1.0 \mathrm{ml} / \mathrm{min}$. for the quantitative analytical purpose, the wavelength was selected as $254 \mathrm{~nm}$.

Initially, standard solution $150 \mu \mathrm{g} / \mathrm{ml}$ was injected into column five times and the retention time of Loxapine succinate was found to be $10.783 \mathrm{~min}$. Then the same concentration of sample solution was injected into the system and the resulting chromatogram was recorded.

Method Validation: The developed method was validated as per the USP and ICH guideline Q2(R1).

Specificity: The specificity of the method was evaluated to ensure there was no interference from the placebo components or from products resulting from forced degradation.

\section{Forced Degradation Studies:}

Acid Degradation Sample: Accurately weighed and transferred Loxapine succinate equivalent to 75 $\mathrm{mg}$ of loxapine into $50 \mathrm{ml}$ volumetric flask. Add 10 $\mathrm{ml} 1 \mathrm{~N} \mathrm{HCl}$ solution. Keep solution at room temperature for $5 \mathrm{~h}$. After $5 \mathrm{~h}$ neutralize with $10 \mathrm{ml}$ of $1 \mathrm{~N} \mathrm{NaOH}$. Add diluent about $50 \%$ of flask volume. Sonicate for $30 \mathrm{~min}$ with intermittent shaking, volume made up to mark with diluent. Solution filter using $0.45 \mu \mathrm{m}$ PVDF filter after $5 \mathrm{ml}$ of filtrate discarded. Pipette out $5 \mathrm{ml}$ of the stock solution into $50 \mathrm{ml}$ volumetric flask, volume made up to mark with diluent. Results are shown in Fig. 4 and Table 3.

Base Degradation Sample: Accurately weighed and transferred Loxapine succinate equivalent to 75 $\mathrm{mg}$ of loxapine into $50 \mathrm{ml}$ volumetric flask. Add 10 $\mathrm{ml} 0.1 \mathrm{~N} \mathrm{NaOH}$ solution. Keep solution at room 
temperature for $5 \mathrm{~h}$. After $5 \mathrm{~h}$ neutralize with $10 \mathrm{ml}$ of $0.1 \mathrm{~N} \mathrm{HCl}$. Add diluent about $50 \%$ of flask volume. Sonicate for $30 \mathrm{~min}$ with intermittent shaking, volume made up to mark with diluent. Solution filter using $0.45 \mu \mathrm{m}$ PVDF filter after $5 \mathrm{ml}$ of filtrate discarded. Pipette out $5 \mathrm{ml}$ of the stock solution into $50 \mathrm{ml}$ volumetric flask; volume made up to mark with diluent. Results are shown in Fig. 5 and Table 4.

Peroxide Degradation Sample: Accurately weighed and transferred Loxapine succinate equivalent to $75 \mathrm{mg}$ of loxapine into $50 \mathrm{ml}$ volumetric flask. Add $10 \mathrm{ml} 30 \% \mathrm{H}_{2} \mathrm{O}_{2}$ solution. Keep solution at room temperature for $5 \mathrm{~h}$. Add diluent about $50 \%$ of flask volume. Sonicate for 30 min with intermittent shaking, volume made up to mark with diluent. Solution filter using $0.45 \mu \mathrm{m}$ PVDF filter after $5 \mathrm{ml}$ of filtrate discarded. Pipette out $5 \mathrm{ml}$ of the stock solution into $50 \mathrm{ml}$ volumetric flask; volume made up to mark with diluent. Results are shown in Fig. 6 and Table 5.

Thermal Degradation Sample: Accurately weighed and transferred Loxapine succinate equivalent to $75 \mathrm{mg}$ of loxapine into $50 \mathrm{ml}$ volumetric flask. Keep at $85{ }^{\circ} \mathrm{C}$ for 7 days in vaccum oven. Add diluent about 50\% of flask volume. Sonicate for $30 \mathrm{~min}$ with intermittent shaking, volume made up to mark with diluent. Solution filter using $0.45 \mu \mathrm{m}$ PVDF filter after $5 \mathrm{ml}$ of filtrate discarded. Pipette out $5 \mathrm{ml}$ of the stock solution into $50 \mathrm{ml}$ volumetric flask; volume made up to mark with diluent. Results are shown in Fig. 7 and Table 6.

Photolytic Degradation Sample: Put Capsule Sample into UV Chamber for 7 days to complete one ICH cycle accurately weighed and transferred Loxapine succinate equivalent to $75 \mathrm{mg}$ of loxapine into $50 \mathrm{ml}$ volumetric flasks. Add diluent about $50 \%$ of flask volume. Sonicate for $30 \mathrm{~min}$ with intermittent shaking, volume made up to mark with diluent. Solution filter using $0.45 \mu \mathrm{m}$ PVDF filter after $5 \mathrm{ml}$ of filtrate discarded. Pipette out $5 \mathrm{ml}$ of the stock solution into $50 \mathrm{ml}$ volumetric flask; volume made up to mark with diluent. Results are shown in Fig. 8 and Table 7.

Results for \% degradation and \% assay after degradation were shown in Table 8.
Linearity: The concentration range $75,120,150$, 180 and $225 \mu \mathrm{g} / \mathrm{ml}$ was injected into the system. Linearity was evaluated by linear regression analysis which was obtained by plotting the Loxapine succinate against peak area. The regression coefficient was found to be 0.999 . linearity data were shown in Table 9.

Accuracy: The accuracy of the method was determined at three different concentration levels $50 \%, 100 \%$ and $150 \%$ of target concentration (150 $\mu \mathrm{g} / \mathrm{ml}$ ) by recovery studies. The recovery studies were carried out in triplicate on composite blend collected from 20 capsules of Loxapine succinate and analyzed as per the proposed method.

Individual recovery was found to be in the range of $97.0 \%$ to $103 \%$ and mean recovery was found to be in a range of $98 \%$ to $102 \%$. The results of accuracy revealed that the method was accurate. Results for accuracy were shown in Table $\mathbf{1 0}$.

Precision: Repeatability study was carried out by estimating six determination of Loxapine succinate with $150 \mu \mathrm{g} / \mathrm{ml}$. The intraday precision study of loxapine succinate was carried out by estimating the peak response for three determination on the same day with $120 \mu \mathrm{g} / \mathrm{ml}, 150 \mu \mathrm{g} / \mathrm{ml}$ and 180 $\mu \mathrm{g} / \mathrm{ml}$ concentration and interday precision study of Loxapine succinate was carried out by estimating the peak response for three determination on different days using $120 \mu \mathrm{g} / \mathrm{ml}, 150 \mu \mathrm{g} / \mathrm{ml}$ and 180 $\mu \mathrm{g} / \mathrm{ml}$.

SD and \% RSD was calculated and found to be within limits. The results of the precision study revealed that the method was precise as shown in Table 11, 12, 13.

Robustness: The Robustness of the analytical method was determined by analysis of aliquots from the homogenous sample by varying the chromato-graphic parameters like change in flow rate, change in column oven temperature, change in mobile phase ratio, change in wavelength, change in HPLC column and their impact on retention time and peak area were studied.

The method was demonstrated to be robust over an acceptable working range of its HPLC operational parameters. Results are shown in Table 14. 


\section{RESULTS AND DISCUSSION:}

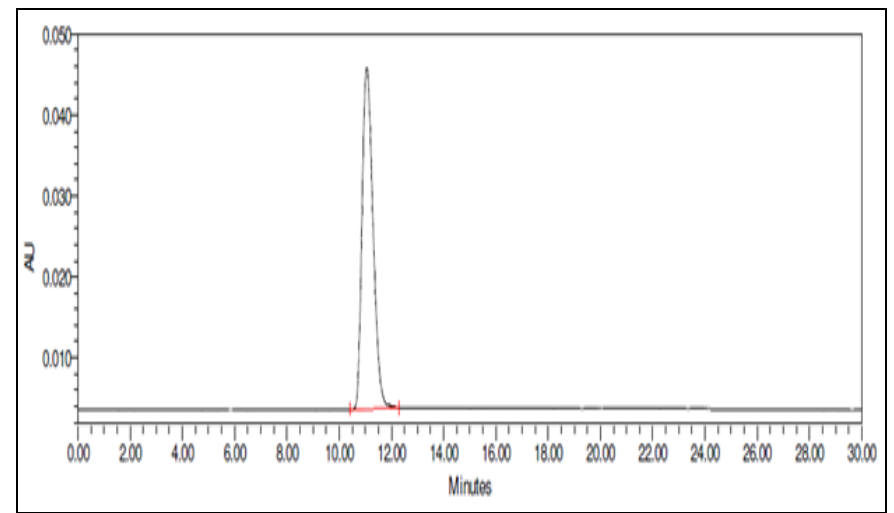

FIG. 2: STANDARD CHROMATOGRAM FOR LOXAPINE SUCCINATE $150 \mu \mathrm{g} / \mathrm{ml}$

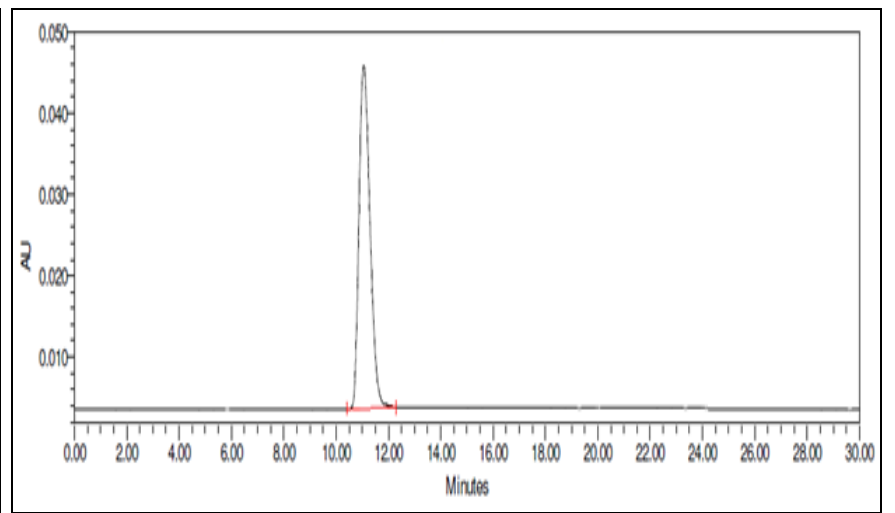

FIG. 3: SAMPLE CHROMATOGRAM FOR LOXAPINE SUCCINATE $150 \mu \mathrm{g} / \mathrm{ml}$

TABLE 1: STANDARD LOXAPINE SUCCINATE

\begin{tabular}{ccccccc} 
Peak Name & RT & Area & USP Tailing & USP Plate count & Purity Angle & Purity Threshold \\
\hline Loxapine & 10.783 & 552387 & 1.12 & 23495 & 1.276 & 1.735 \\
\hline
\end{tabular}

TABLE 2: FOR SAMPLE LOXAPINE SUCCINATE

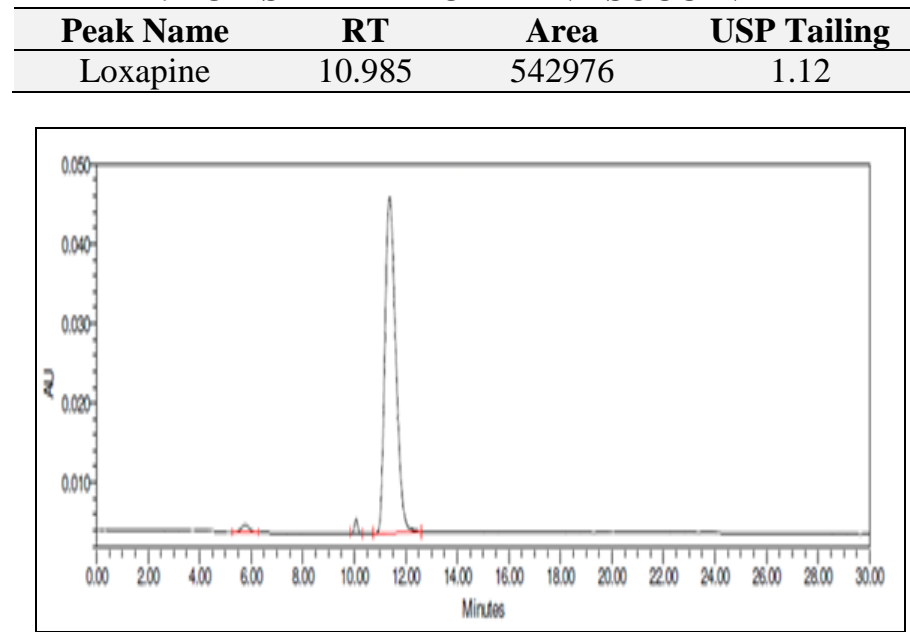

FIG. 4: CHROMATOGRAM FOR LOXAPINE SUCCINATE ACID DEGRADATION

\begin{tabular}{ccc} 
USP Plate count & Purity Angle & Purity Threshold \\
\hline 23478 & 1.324 & 1.712 \\
\hline
\end{tabular}

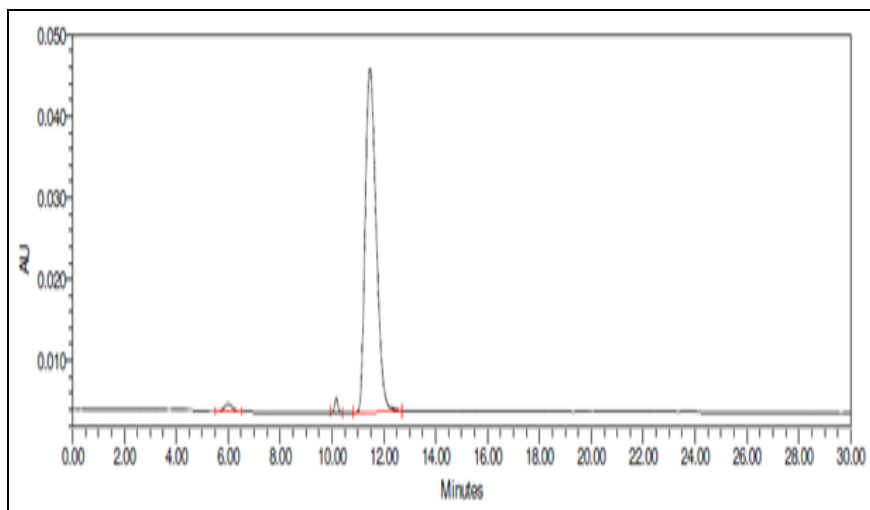

BASE DEGRADATION

TABLE 3: FOR ACID DEGRADATION

\begin{tabular}{ccccccc}
\hline Peak Name & RT & Area & USP Tailing & USP Plate count & Purity Angle & Purity Threshold \\
\hline UnkImp & 5.872 & 20487 & 1.45 & 4236 & 2.875 & 3.986 \\
UnkImp & 9.985 & 38125 & 1.01 & 3478 & 1.798 & 1.143 \\
Loxapine & 10.823 & 501254 & 1.20 & 21870 & 0.998 & 1.572 \\
\hline
\end{tabular}

TABLE 4: FOR BASE DEGRADATION

\begin{tabular}{ccccccc}
\hline Peak Name & RT & Area & USP Tailing & USP Plate count & Purity Angle & Purity Threshold \\
\hline UnkImp & 5.932 & 18765 & 1.54 & 4187 & 1.246 & 2.467 \\
UnkImp & 9.879 & 35398 & 1.05 & 3562 & 5.986 & 4.651 \\
Loxapine & 10.756 & 511659 & 1.21 & 22870 & 1.876 & 2.246 \\
\hline
\end{tabular}

TABLE 5: FOR PEROXIDE DEGRADATION

\begin{tabular}{|c|c|c|c|c|c|c|}
\hline Peak Name & RT & Area & USP Tailing & USP Plate count & Purity Angle & Purity Threshold \\
\hline Loxapine & 10.752 & 522541 & 1.21 & 22212 & 1.684 & 1.709 \\
\hline \multicolumn{7}{|c|}{ TABLE 6: FOR THERMAL DEGRADATION } \\
\hline Peak Name & RT & Area & USP Tailing & USP Plate count & Purity Angle & Purity Threshold \\
\hline Loxapine & 10.687 & 542121 & 1.21 & 25687 & 1.342 & 1.673 \\
\hline
\end{tabular}




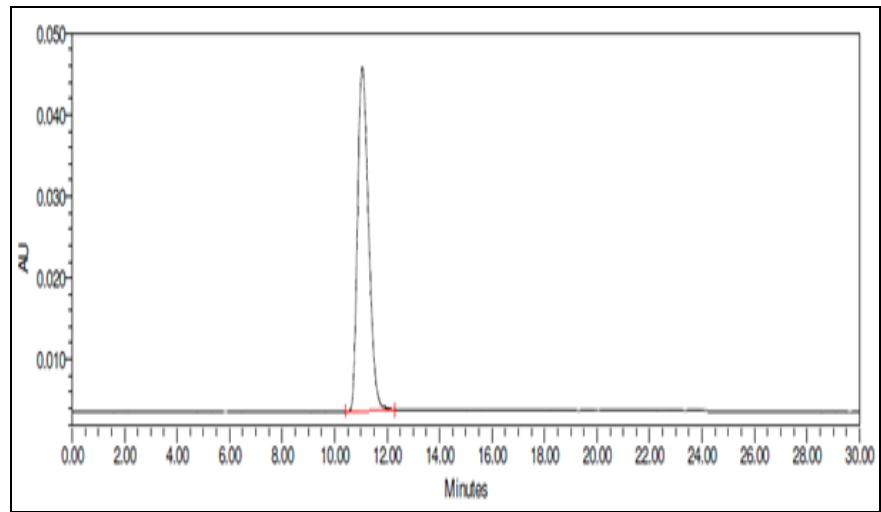

FIG. 6: CHROMATOGRAM FOR LOXAPINE SUCCINATE- PEROXIDE DEGRADATION

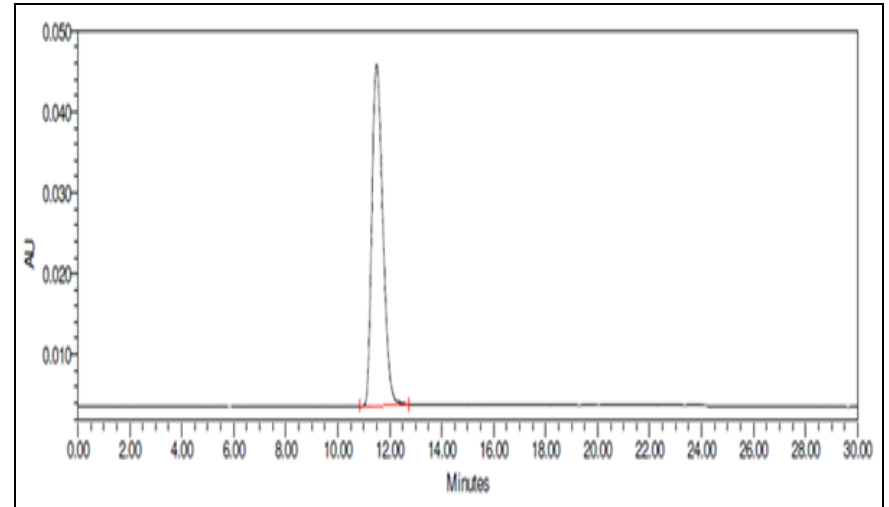

FIG. 7: CHROMATOGRAM FOR LOXAPINE SUCCINATE THERMAL DEGRADATION

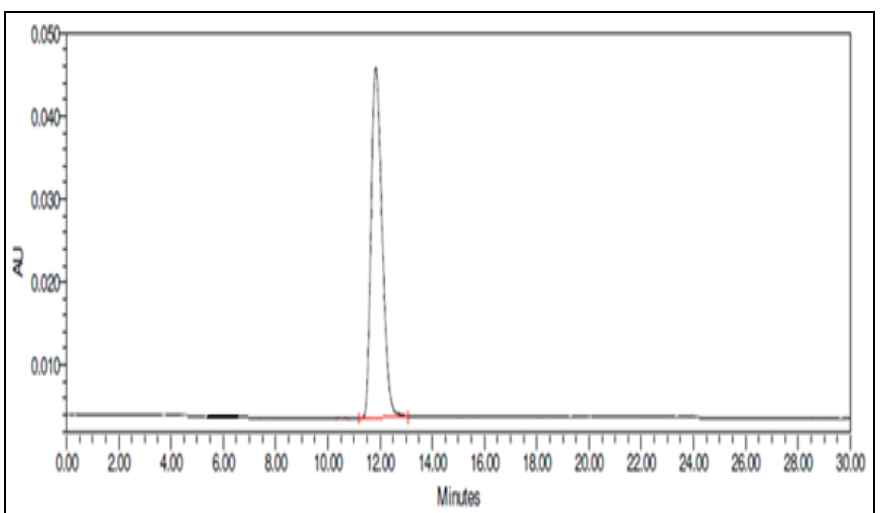

FIG. 8: CHROMATOGRAM FOR LOXAPINE SUCCINATEPHOTOLYTIC DEGRADATION

TABLE 7: FOR PHOTOLYTIC DEGRADATION

\begin{tabular}{ccccccc}
\hline Peak Name & RT & Area & USP Tailing & USP Plate count & Purity Angle & Purity Threshold \\
\hline Loxapine & 10.821 & 539921 & 1.17 & 26009 & 2.286 & 3.245 \\
\hline
\end{tabular}

TABLE 8: FORCED DEGRADATION STUDIES FOR LOXAPINE SUCCINATE

\begin{tabular}{ccccc}
\hline Stressed condition & Retention time $(\mathbf{m i n})$ & Peak area & \% Purity & \% of degradation \\
\hline Standard drug & 10.547 & 545432 & 100 & - \\
Acid degradation & 10.823 & 501254 & 90.95 & 9.0 \\
Alkaline degradation & 10.756 & 511659 & 92.83 & 7.2 \\
Oxidative Degradation & 10.752 & 522541 & 94.81 & 5.2 \\
Thermal degradation & 10.687 & 542121 & 98.36 & 1.6 \\
Photolytic degradation & 10.821 & 539921 & 97.96 & 2.0 \\
\hline
\end{tabular}

TABLE 9: FOR LOXAPINE SUCCINATE- LINEARITY

\begin{tabular}{ccc}
\hline Level \% & Concentration $(\boldsymbol{\mu g} / \mathbf{m l})$ & Mean peak area \\
\hline 50 & 75 & 272175 \\
80 & 120 & 437832 \\
100 & 150 & 543456 \\
120 & 180 & 657752 \\
150 & 225 & 815184 \\
\hline
\end{tabular}

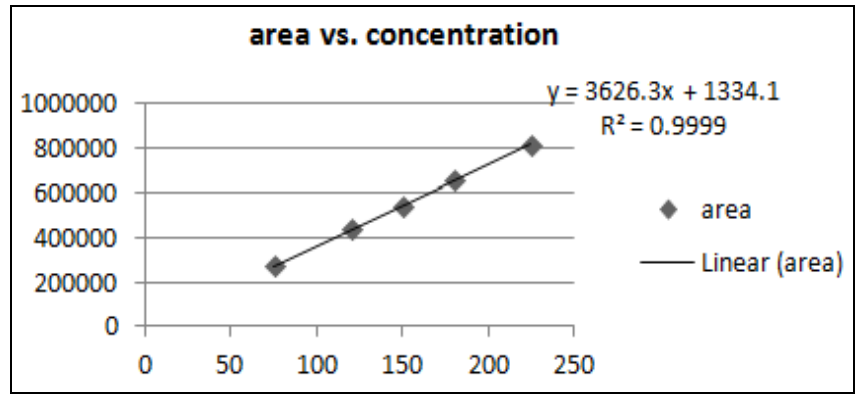

International Journal of Pharmaceutical Sciences and Research 
TABLE 10: RECOVERY STUDIES FOR LOXAPINE SUCCINATE

\begin{tabular}{ccccccc}
\hline $\begin{array}{c}\text { Level of } \\
\text { recovery }\end{array}$ & $\begin{array}{c}\text { Amt added } \\
(\boldsymbol{\mu g} / \mathbf{m l})\end{array}$ & $\begin{array}{c}\text { Peak } \\
\text { area }\end{array}$ & $\begin{array}{c}\text { Amt } \\
\text { recovered }\end{array}$ & $\begin{array}{c}\text { \% } \\
\text { recovery }\end{array}$ & $\begin{array}{c}\text { Mean } \\
\text { \%recovery }\end{array}$ & $\begin{array}{c}\text { \% } \\
\text { RSD }\end{array}$ \\
\hline 50 & 75 & 275645 & 76.23 & 101.63 & 100.20 & 1.29 \\
50 & 75 & 270789 & 74.90 & 99.86 & & \\
50 & 75 & 268709 & 74.33 & 99.10 & & 0.74 \\
100 & 150 & 544560 & 149.75 & 99.83 & 99.04 & \\
100 & 150 & 539481 & 148.37 & 98.91 & & \\
100 & 150 & 536480 & 147.54 & 98.36 & & \\
150 & 225 & 814545 & 223.58 & 99.37 & 100.05 & \\
150 & 225 & 823989 & 226.16 & 100.51 & & \\
150 & 225 & 821883 & 225.59 & 100.26 & & \\
\hline
\end{tabular}

TABLE 11: REPEATABILITY STUDY

\begin{tabular}{cc}
\hline Concentration & Peak area \\
\hline $150 \mu \mathrm{g} / \mathrm{ml}$ & 546756 \\
& 538917 \\
& 558789 \\
& 545587 \\
& 548483 \\
Average & 556480 \\
$\% \mathrm{SD}$ & 549169 \\
$\%$ RSD & 7351.50 \\
\hline
\end{tabular}

TABLE 12: INTRADAY PRECISION

\begin{tabular}{ccccccc}
\hline $\begin{array}{c}\text { Conc. } \\
\boldsymbol{\mu g} / \mathbf{m l}\end{array}$ & Set-I & Seak area & Mean area & SD & \multirow{2}{*}{ RSD } \\
\cline { 2 - 4 } & 437832 & 436711 & Set-III & & & \\
\hline 120 & 543456 & 542478 & 537812 & 54341248.7 & 6710.033 & 1.55 \\
150 & 657752 & 658321 & 641356 & 652476.3 & 9634.145 & 0.56 \\
\hline
\end{tabular}

TABLE 13: INTERDAY PRECISION

\begin{tabular}{ccccccc}
\hline Conc. & \multicolumn{3}{c}{ Peak area } & Mean area & SD & \% RSD \\
\cline { 2 - 4 } $\boldsymbol{\mu} / \mathbf{m l}$ & Set-I & Set-II & Set-III & & & \\
\hline 120 & 437832 & 426930 & 425421 & 430061 & 6772.046 & 1.57 \\
150 & 543456 & 531546 & 529874 & 534958.7 & 7406.241 & 1.38 \\
180 & 657752 & 646853 & 644370 & 649658.3 & 7118.42 & 1.1 \\
\hline
\end{tabular}

TABLE 14: ROBUSTNESS

\begin{tabular}{|c|c|c|c|c|c|c|c|}
\hline $\begin{array}{l}\text { Change in } \\
\text { parameter }\end{array}$ & Values & $\begin{array}{c}\text { Retention } \\
\text { time }\end{array}$ & $\begin{array}{c}\text { USP } \\
\text { plates }\end{array}$ & $\begin{array}{l}\text { USP } \\
\text { tailing }\end{array}$ & $\begin{array}{c}\% \text { RSD of } \\
\text { standard area }\end{array}$ & $\begin{array}{c}\% \\
\text { assay }\end{array}$ & $\begin{array}{c}\% \\
\text { RSD }\end{array}$ \\
\hline Control & As per method & 10.78 & 23495 & 1.12 & 1.34 & 99.53 & 1.35 \\
\hline \multirow[t]{2}{*}{ Flow rate } & $0.8 \mathrm{ml} / \mathrm{min}$ & 10.54 & 22764 & 1.10 & 1.30 & 99.41 & 1.29 \\
\hline & $1.2 \mathrm{ml} / \mathrm{min}$ & 10.81 & 22542 & 1.10 & 1.31 & 98.88 & 1.29 \\
\hline \multirow[t]{2}{*}{ Wavelength } & $252 \mathrm{~nm}$ & 10.23 & 23985 & 1.20 & 1.33 & 99.34 & 1.36 \\
\hline & $256 \mathrm{~nm}$ & 10.89 & 22563 & 1.10 & 1.31 & 100.87 & 1.34 \\
\hline Column & $25^{\circ} \mathrm{C}$ & 10.78 & 23495 & 1.12 & 1.30 & 99.09 & 1.35 \\
\hline temperature & $35^{\circ} \mathrm{C}$ & 10.78 & 23494 & 1.11 & 1.34 & 99.12 & 1.28 \\
\hline \multirow[t]{2}{*}{$\begin{array}{l}\text { Mobile phase } \\
\text { composition }\end{array}$} & $\begin{array}{c}\text { Water: MeOH: ACN: TEA } \\
\text { 50:10:40:1ml }\end{array}$ & 10.91 & 23652 & 1.12 & 1.35 & 99.32 & 1.38 \\
\hline & $\begin{array}{c}\text { Water: MeOH: ACN: TEA } \\
\text { 30:10:60:1ml }\end{array}$ & 10.87 & 23127 & 1.11 & 1.30 & 99.50 & 1.28 \\
\hline
\end{tabular}

TABLE 15: ASSAY OF CAPSULE DOSAGE FORM (LOXAPINE SUCCINATE)

\begin{tabular}{cccccc}
\hline Label claim & Amount found & \% Assay & Average & SD & \% RSD \\
\hline \multirow{2}{*}{$34 \mathrm{mg}$} & 33.84 & 99.55 & 99.55 & 0.0252 & 0.0253 \\
& 33.86 & 99.58 & & & \\
\hline
\end{tabular}


CONCLUSION: This study presents simple and validated stability-indicating HPLC method for the determination of Loxapine succinate in the presence of its degradation products. The developed method is specific, accurate, precise and robust. All the peaks of the degradation products formed during forced degradation studies were well separated from the analyte peak. Hence, the developed method can be used for routine analysis for the determination of Loxapine succinate in capsule dosage forms.

ACKNOWLEDGEMENT: The authors express sincere thanks to Hetero Drugs Ltd., Hyderabad, Andhra Pradesh for providing a gift sample of Loxapine succinate and Umedica Pvt. Ltd., Vapi for providing necessary facilities to carry out the research work.

CONFLICT OF INTEREST: The authors reveal that there are no conflicts of interest.

\section{REFERENCES:}

1. Barar FSK: Essentials of Pharmacotherapeutics. S. chand and company ltd, fifth Edition 201: 143.

2. Tripathi KD: Essential of Medical Pharmacology. Jaypee publisher, fifth Edition, 2004: 394.

3. Hawland RD: Reviews: Pharmacology. B.I publications, third edition, 2005: 149.
4. www.drugbank.ca/drugs/DB00408

5. www.chemspider.com/chemicalstructure.3827.html

6. Pubchem.ncbi.nlm.nih.gov/compound/Loxapine

7. www.rsc.org/merck-index

8. USP<905> US Pharmacopeia 32 NF 27, Vol- I, the United State Pharmacopoeial Convention, Rockville 2817.

9. Rajendra P and Tushar D: Review on Analytical Method Development and Validation. Journal of Pharmaceutical Analysis 2014; 3: 1-10.

10. Guidance for Industry: Analytical Procedures and Methods Validation of Drugs and Biologics. U.S. Department of Health and Human Services Food and Drug Administration. 2015; 1-13.

11. Bhojan C: Development of UV spectrophotometry and HPTLC techniques for Loxapine in the formulation. International Journal of Chemical and Pharmaceutical Analysis 2017; 4(1).

12. Dammalapati $\mathrm{S}$ and Rudraraju $\mathrm{R}$ : Development and validation of RP-HPLC method for Loxapine in the capsule dosage form. International Journal of Advances in Pharmaceutical Analysis 2015; 5(3): 61-64.

13. Garcia LG and Bares IF: Simultaneous determination of four antipsychotic drugs in plasma by HPLC: Application to the management of acute intoxications. Journal of chromatography $2017 ; 2$ : 257-64.

14. International Conference on Harmonization (ICH) Q2 (R1): Validation of Analytical Procedures: Test and Methodology, Geneva, Switzerland 2005.

15. Validation of Analytical Procedures: Methodology (Q2B), ICH Harmonized Tripartite Guidelines, Geneva 1996.

16. ICH Stability Testing of New Drug Substances and Products Q1A (R2), International Conference on Harmonization 2003.

17. ICH guidelines for impurities in new drug substances Text and methodology Q3A (R2), International Conference on Harmonization 2006

\section{How to cite this article:}

Thakor KA and Pasha TY: Development and validation of stability indicating assay method for determination of loxapine succinate in capsule dosage form. Int J Pharm Sci \& Res 2019; 10(5): 2362-68. doi: 10.13040/IJPSR.0975-8232.10(5).2362-68.

All @ 2013 are reserved by International Journal of Pharmaceutical Sciences and Research. This Journal licensed under a Creative Commons Attribution-NonCommercial-ShareAlike 3.0 Unported License.

This article can be downloaded to Android OS based mobile. Scan QR Code using Code/Bar Scanner from your mobile. (Scanners are available on Google Play store) 